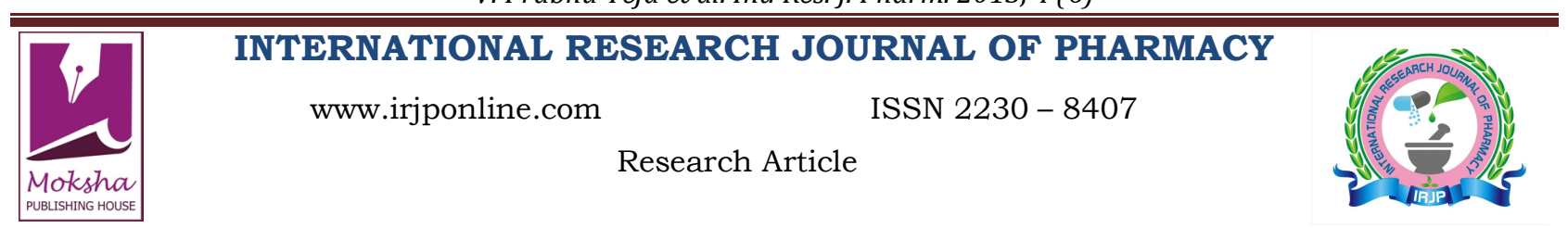

\title{
PRELIMINARY PHYTOCHEMICAL INVESTIGATION AND IN VITRO ANTIMICROBIAL ACTIVITY OF ETHANOLIC EXTRACT OF SONNERATIA APETALA PLANT
}

\author{
V. Prabhu Teja, K.Ravishankar* \\ Sri Sai Aditya Institute of Pharmaceutical Sciences and Research, ADB Road, Surampalem, India \\ *Corresponding Author Email: kravishankar_1963@yahoo.com
}

Article Received on: 16/03/13 Revised on: 08/04/13 Approved for publication: 11/05/13

DOI: 10.7897/2230-8407.04619

IRJP is an official publication of Moksha Publishing House. Website: www.mokshaph.com

(C) All rights reserved.

\section{ABSTRACT}

The aim of present study is to investigate the phytochemical constituents and antimicrobial activity of Ethanolic extract of Sonneratia apetala. Preliminary Phytochemical tests revealed the presence of alkaloids, flavonoids, tannins, saponins, phytosterols and carbohydrates. Antimicrobial activity was evaluated by Agar well Diffusion method. In vitro screening of Sonneratia apetala mangrove Ethanolic plant extract showed species specific activity in inhibiting growth of bacteria and fungi. The Ethanolic plant extract showed good activity against selected gram-positive bacteria (Bacillus subtilis, Staphylococcus aureus, Staphylococcus werneri), gram-negative bacteria (Pseudomonas putida, Escherichia coli, Pseudomonas aeruginosa, Proteus mirabilis, Klebsiella pneumonia) and fungal strain (Candida albicans). The observations revealed significant zone of inhibition and supports to antimicrobial activity. The bioactive compounds responsible for these antimicrobial activities could be isolated and identified to develop a new drug of pharmaceutical interest.

Keywords: Mangrove plant, Sonneratia apetala, antimicrobial activity, Agar well diffusion method.

\section{INTRODUCTION}

Medicinal plants, used in the traditional treatments of various diseases on an empirical basis ${ }^{1-5}$. Herbal medicines have been widely practiced throughout the world from ancient time. These medicines are safe and environment friendly. Nearly $80 \%$ of the world population depends upon traditional systems of health care ${ }^{6}$. In India, 9500 herbal medicinal plants and also 8000 higher plants have been used in the Indian medicinal industries. The potential for developing antimicrobials from higher plants appears rewarding as it might lead to the development of phytomedicine, which would play a prominent role against microbes. Plant-based antimicrobials have enormous therapeutic potential as they can serve purpose with lesser side effects that are often associated with synthetic antimicrobials ${ }^{7}$. Several plants and herb species used traditionally have potential antimicrobial and antiviral properties ${ }^{8,9}$ and this has raised the optimism of scientists about the future phyto-antimicrobial agents ${ }^{10}$. In recent years secondary plant metabolites and phytochemicals, previously with unknown pharmacological activities, have been extensively investigated as a source of medicinal agents ${ }^{11}$. Thus it is anticipated that phytochemicals with adequate antibacterial efficacy will be used for the treatment of many bacterial infections ${ }^{12}$. Several phytochemical surveys have been published, including the random sampling approach which involved some plant accessions collected from all parts of the world. The major chemical substances of interest in these surveys were the alkaloids, steroids and saponins, however other diverse are naturally occurring phytocomponents such as flavonoids, tannins, unsaturated steroids, triterpenoids and essential oils ${ }^{13}$. Mangroves are a collection of plants growing in saline coastal habitats and are rich sources of secondary metabolites which possess interesting bioactive properties especially antimicrobial activity. Sonneratia apetala Buch. Ham, also known as mangrove apple plant belongs to Sonneratiaceae ${ }^{14}$ family. It is grown as a tree or shrub along seaward fringes and intertidal areas like Coringa, Kakinada (Andhra Pradesh, India). This plant has been traditionally used to treat hepatitis $^{15}$. The literature also reports that the leaf part of the plant is widely used for dysentery, sprain and bruises, in treatment of eye troubles (such as cataract) and open sores in children ears and also in heart troubles ${ }^{16}$. However, very little is known about the specific chemical constituents present in this plant. So far biological activities have not carried out on the plant and the present study aims to determine Phytochemical constituents and antimicrobial activity on selected gram positive, gram negative bacterial and fungal strain.

\section{MATERIALS AND METHODS \\ Plant material}

Plant parts (leaves, bark, pneumatophores) of Sonneratia apetala were collected randomly from mangrove forest, Coringa near to Kakinada East Godavari district, Andhra Pradesh, India. The freshly collected roots of plant were cleaned from dirt, dried under shade and then coarsely powdered manually.

\section{Extraction of plant material}

Known amount of coarsely powdered plant material was macerated in ethanol for a period of 7days and then subjected to hot percolation for $8 \mathrm{~h}$. The solution was then filtered concentrated and dried in desiccators. The yield of Ethanolic extract was found to be $8.3 \% \mathrm{w} / \mathrm{w}$.

\section{Bacterial and fungal strains}

The antimicrobial activity of Sonneratia apetala was carried on Staphylococcus auerus (ATCC BAA1026), Bacillus subtilis (ATCC 11774), Staphylococcus warneri (ATCC 27836), Eschereria coli (ATCC 10536), Klebsiella pneumonia (ATCC 33495), Pseudomonas putida, Pseudomonas aerugenosa (ATCC 10662), Proteus microbilis (ATCC 14153) and Candida albicans.

\section{Phytochemical investigation}

Phytochemical $^{17}$ tests were carried out on all extracts for qualitative determination of phytochemical constituents ${ }^{18}$. 
V. Prabhu Teja et al. Int. Res. J. Pharm. 2013, 4 (6)

Table1: Phytochemical screening of Ethanolic extract of Sonneratia apetala

\begin{tabular}{|c|c|c|}
\hline Chemical constituent & Chemical test & Ethanolic extract \\
\hline Alkaloids & $\begin{array}{c}\text { Dragendroff's test } \\
\text { Mayers test } \\
\text { Hagers test }\end{array}$ & $\begin{array}{l}+ \\
+ \\
+ \\
\end{array}$ \\
\hline Carbohydrates & $\begin{array}{l}\text { Molisch test } \\
\text { Benedict test } \\
\text { Fehling's test }\end{array}$ & $\begin{array}{l}+ \\
+ \\
+\end{array}$ \\
\hline Flavonoids & $\begin{array}{c}\text { Lead acetate test } \\
\mathrm{Zn}-\mathrm{HCl} \text { reduction test } \\
\mathrm{NaOH} \text { test }\end{array}$ & $\begin{array}{l}+ \\
+ \\
+\end{array}$ \\
\hline Glycosides & $\begin{array}{c}\text { General test } \\
\text { Mod.Borntragers test }\end{array}$ & $\begin{array}{l}- \\
-\end{array}$ \\
\hline Proteins & $\begin{array}{l}\text { Xanthoprotein test } \\
\text { Millions test }\end{array}$ & $\begin{array}{l}- \\
-\end{array}$ \\
\hline Saponins & $\begin{array}{l}\text { Foam test } \\
\text { Froth test }\end{array}$ & $\begin{array}{l}+ \\
+\end{array}$ \\
\hline Tannins & $\begin{array}{l}\text { Lead acetate test } \\
\text { Salkowskii test }\end{array}$ & $\begin{array}{l}+ \\
+\end{array}$ \\
\hline
\end{tabular}

Table 2: Zone of inhibition of Ethanolic extract of Sonneratia apetala

\begin{tabular}{|c|c|c|c|c|}
\hline \multirow{2}{*}{ Microorganism } & \multicolumn{4}{|c|}{ Zone of inhibition(mm) } \\
\cline { 2 - 5 } & \multicolumn{3}{|c|}{ Ethanolic Extract } & Standard \\
\cline { 2 - 5 } & $\mathbf{2 5 m g / m l}$ & $\mathbf{5 0 m g} / \mathbf{m l}$ & $\mathbf{1 0 0} \mathbf{m g} / \mathbf{m l}$ & $\mathbf{2 5} \boldsymbol{\mu g} / \mathbf{m l}$ \\
\hline Gram-positive bacteria & & & & \\
Bacillus subtilis & $15 \pm 0.23$ & $16 \pm 0.11$ & $19 \pm 0.17$ & $18 \pm 015$ \\
Staphylococcus aureus & $15 \pm 0.12$ & $16 \pm 0.15$ & $19 \pm 0.17$ & $18 \pm 0.26$ \\
Staphylococcus werneri & $15 \pm 0.32$ & $17 \pm 0.16$ & $20 \pm 0.31$ & $17 \pm 0.14$ \\
\hline Gram-negative bacteria & & & & \\
Pseudomonas putida & $14 \pm 0.15$ & $16 \pm 0.13$ & $17 \pm 0.21$ & $19 \pm 0.21$ \\
Escherichia coli & $14 \pm 0.12$ & $16 \pm 0.16$ & $18 \pm 0.15$ & $18 \pm 0.15$ \\
Pseudomonas aeruginosa & $13 \pm 0.31$ & $14 \pm 0.21$ & $16 \pm 0.24$ & $19 \pm 0.32$ \\
Proteus mirabilis & $14 \pm 0.41$ & $15 \pm 0.17$ & $17 \pm 0.13$ & $19 \pm 0.18$ \\
Klebsiella pneumonia & $12 \pm 0.14$ & $14 \pm 0.23$ & $17 \pm 0.41$ & $19 \pm 0.17$ \\
\hline Fungal strain & & & & \\
Candida albicans & $9 \pm 0.15$ & $11 \pm 0.15$ & $15 \pm 0.12$ & $15 \pm 0.21$ \\
\hline
\end{tabular}

All the values are expressed as Mean \pm SEM

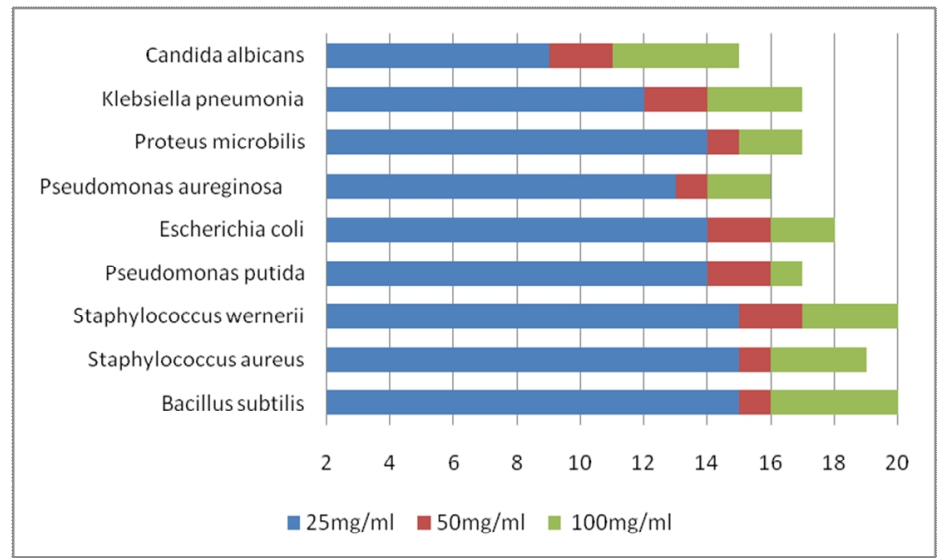

Figure 1: Zone of inhibition of Ethanolic extract of Sonneratia apetala

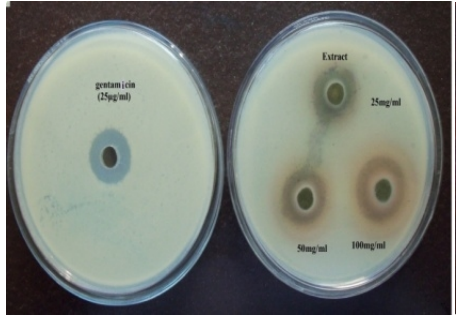

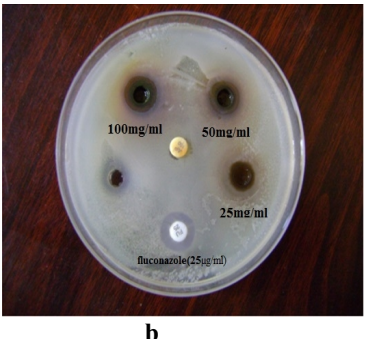

b

Zone of inhibition antimicrobial activity

Figure 2:(a) shows Antibacterial effect of std Gentamicin $(25 \mu \mathrm{g} / \mathrm{ml})$, test sample of concentrations $(25,50,100 \mathrm{mg} / \mathrm{ml})$ on staphylococcus warneri (b) shows anti fungal effect of fluconazole $(25 \mu \mathrm{g} / \mathrm{ml})$, test sample $(25,50,100 \mathrm{mg} / \mathrm{ml})$ on Candida albicans 


\section{Antibacterial assay}

Antibacterial activity ${ }^{19-21}$ of crude extract was tested through agar well diffusion method. For this, agar plates were prepared separately and overnight culture of test bacterial strains were seeded individually over the the surface of agar plates. Approximately $6 \mathrm{~mm}$ diameter wells were punctured over the agar plates using sterile cork borer. The extracts were then prepared at a concentraions of $25,50,100 \mathrm{mg} / \mathrm{ml}$ by dissloving in DMSO. The wells were then filled with $50 \mu \mathrm{L}$ of extract. Gentamicin $(25 \mu \mathrm{g} / \mathrm{ml})$ was used as positive control. The plates were then incubated at $37^{\circ} \mathrm{c}$ for $24 \mathrm{~h}$. The assay was carried out in triplicate. The antibacterial activity of the extract was determined by measuring the the diameter of inhibition zone around the well filled with extract.

\section{Antifungal assay}

Antifungal activity of crude extract was tested through agar well diffusion method. For this, Sabouraud dextrose agar plates (SDA) were prepared. Then with a sterile cotton swab, $72 \mathrm{~h}$ culture of fungal strain were seeded over the the surface of SDA plates. Approximately $6 \mathrm{~mm}$ diameter wells were punctured over the agar plates using sterile cork borer. The extracts were then prepared at a concentraions of $25,50,100 \mathrm{mg} / \mathrm{ml}$ by dissloving in DMSO. The wells were then filled with $50 \mu \mathrm{L}$ of extract.Fluconazole $(25 \mu \mathrm{g} / \mathrm{ml})$ was used as positive control. The plates were then incubated at $37^{\circ} \mathrm{c}$ for $48 \mathrm{~h}$. The assay was carried out in triplicate. The antibacterial activity of the extract was determined by measuring the the diameter of inhibition zone around the well filled with extract. ${ }^{20}$

\section{RESULTS}

Preliminary Phytochemical tests revealed the presence of alkaloids, flavonoids, tannins, saponins, phytosterols and carbohydrates Table 1. Antimicrobial activity was evaluated by Agar well Diffusion method. In vitro screening of Sonneratia apetala mangrove Ethanolic plant extract showed species specific activity in inhibiting growth of bacteria and fungi in a concentration dependent manner and was comparable with standard drug Table 2 and Figure 1, 2. The gram-positive bacteria were more susceptible than gramnegative bacteria. This may be due to the presence of an outer membrane in gram-negative bacteria which acts as a barrier to many environmental substances including antibiotics. Results from present study indicate potential use of Sonneratia apetala in treatment of various pathogenic diseases as described in Ayurvedic literature.

\section{DISCUSSION}

In present era, plant and herb resources are abundant, but these resources are dwindling fast due to the onward march of civilization ${ }^{22}$. Although, a significant number of studies have been carried out to programmes have been initiated on crude plant materials. It also been widely observed and accepted that the medicinal value of plants lies in the bioactive phytocomponents present in the plants ${ }^{23}$. In this investigation, the active phytocomponents of Sonneratia apetala activity of the plant extracts was assayed in vitro by agar well diffusion method against 8 bacterial and 1 fungal species. Table 2, summarizes the microbial growth inhibition of ethanol extracts of the plant. The traditional plants may represent new sources of anti-microbial with stable, biologically active components that can establish a scientific base for the use of plants in modern medicine ${ }^{24}$. Preliminary Phytochemical tests revealed the presence of alkaloids, flavonoids, tannins, saponins, phytosterols and carbohydrates Table 1.

\section{CONCLUSION}

Preliminary Phytochemical tests showed the presence of several Phytochemical constituents in Sonneratia apetala. The results obtained from the antibacterial study concludes that the Ethanolic extract of Sonneratia apetala possesses good antibacterial indicating its effectiveness against both gram positive and gram negative microbes. The antifungal activity was evaluated by using Sabouraud dextrose agar well diffusion method and the results shows test sample has significant antifungal activity.

\section{REFERENCES}

1. Hutchings A and J Van Staden. Plants used for stress-related ailments in traditional Zulu, Xhosa and Sotho medicine: part 1 plants used for headaches. J. Ethnopharmacol 1994; 43: 89-124. http://dx.doi.org/ 10.1016/0378-8741(94)90008-6

2. Hutchings A, AH Scott, G Lewis and A Cunningham. Zulu Medicinal Plants; An Inventory. University of Natal Press, Scottsville, South Africa; 1996. p. 195-196

3. Jager AK, A Hutchings and J Van Staden. Screening of Zulu medicinal plants for prostaglandin-synthesis inhibitors. J. Ethnopharmacol 1996; 52: 95-100. http://dx.doi.org/10.1016/0378-8741(96)01395-5

4. Salie F, PFK Eagles and HMJ Leng. Preliminary phytochemical screening of four South African Asteraceae species. J. Ethnopharmacol 1996; 52: 27-33. http://dx.doi.org/10.1016/0378-8741(96)01381-5

5. McGaw LJ, AK Jager and J Van Staden. Prostaglandin synthesis inhibitory activity in Zulu Xhosa and Sotho medicine plants. Phytotherapy Res 1997; 11: 113-117. http://dx.doi.org/10.1002/(SICI) 1099-1573(199703)11:2<113::AID-PTR27>3.0.CO;2-S

6. Rajadurai M, VG Vidhya, M Ramya and A Bhaskar. Ethno-medicinal plants used by the traditional Healers of pachamalai Hills, India. Ethnomed 2009; 3(1): 41

7. Purohit SS and SP Vyas. Medicinal Plant: Cultivation A Scientific Approach. Agrobios (India); 2007. p. 648

8. Shelef LA. Antimicrobial effects of species. J. Food Safety 1983; 6: 2944. http://dx.doi.org/10.1111/j.1745-4565.1984.tb00477.x

9. Zaika LL. Spices and herbs: Their antimicrobial activity and its determination. J. Food Safety 1988; 9: 97-118. http://dx.doi.org/10.1111 j.1745-4565.1988.tb00511.x

10. Das S, A Mujib, S Das, S Pal and S Dey. Biotechnology of medicinal plants: Recent advances and potential. In: Role of biotechnology in medicinal and aromatic plants. Vol.2-Ukaaz Publication, Hyderabad, India; 1998. p. 126-139

11. Krishnaraju AV, VN Tayi Rao, D Sundararaju, M Vanisree, HS Tsay and GV Subbaraju. Biological screening of medicinal plants collected from Eastern Ghats of India using Artemia salina (Brine Shrimp Test). Int. J. Appl. Sci. and Engineering 2006; 2: 115-25.

12. Balandrin MF, AJ Kjocke and ES Wurtele. Natural plant chemicals sources of Industrial and mechanical materials. Sci 1985; 228: 1154160. http://dx.doi.org/10.1126/science. 3890182

13. Lozoya $\mathrm{M}$ and $\mathrm{X}$ Lozaya. Pharmacological properties in vitro of various extracts of Mimosa pudica. Tepescohuite Arch Invest Mex; 1989. p. 8793 PMid:2764672

14. Varaprasad Bobbrala, Varahalarao Vadalapudi and Naidu K Chandrasekhara. Mangrove plant Sonneratia apetala antimicrobial activity on selected pathogenic microorganisms. Oriental Journal of Chemistry 2009; 25(2): 445-447.

15. WM Bandaranayake. Bioactivities, bioactive compounds and chemical constituents of mangrove Plants, Wetlands Ecology and Management 2002; 10: 421-452. http://dx.doi.org/10.1023/A:1021397624349

16. Bandaranayake WM. Survey of mangrove plants from Northern Australia for phytochemical assessment of antimicrobial activity. In: Methods of constituents and UV-absorbing compounds. Current microbiology. Eds. JR Norris and Ribbons DW. Topics in Phytochemistry 1995; 14: 69-78.

17. Panda Sangram Keshari, Debasis Pati, Mishra SK, Sahu S, Tripathy B, Nayak L. Phytochemical Investigation and Antimicrobial Activity of Methanolic Extract of Sonneratia apetala Buch-Ham. Areal parts, International Journal of Pharmaceutical and Biological Archives 2012; 3(1): 79-83.

18. Evans WC, Trease and Evans Pharmacognosy, Aspects of Asian Medicine and its Practice in the West, $15^{\text {th }}$ ed, Elsevier Science Limited, Edinburgh; 2002. p. 469-687 
19. D Jaimini, C Sarkar, Aaftab A Shabnam and BL Jadhav. Evaluation of Antibacterial Properties of Mangrove Plant Sonneratia apetala Buch. Ham Leaf, World Applied Sciences Journal 2011; 14(11).

20. Ramasamy Ramasubburayan, Santhiyagu Prakash, Palanisamy Iyapparaj, Manohar Siva mahizha, Muthusamy Usha, Arunachalam Palavesam, Grasian Immanuel. Antibacterial, antifungal and cytotoxic properties of chosen mangroves, Asian Pacific Journal of Tropical Biomedicine 2012; 967-973.

21. SJ Hossain and MH Basar and B Rokeya and KMT Arif and MS Sultana and $\mathrm{MH}$ Rahman. Evaluation of antioxidant, antidiabetic and antibacterial activities of the fruit of Sonneratia apetala (Buch.-Ham.), Orient Pharm Exp Med DOI 10.1007/s13596-012-0064-4.

22. Vogel HG. Similarities between Various Systems of traditional medicine. Considerations for the future of ethnopharmacology. J.
Ethnopharmacocol 1991; 35: 179-90. http://dx.doi.org/10.1016/03788741(91)90071-K

23. Veeramuthu D, A Muniappan and I Savarimuthu. Antimicrobial activity of some Ethnomedicinal plants used by paliyar tribe from Tamilnadu, India. BMC Complementory and alternative Medicine 2006; 6(35).

24. Gandhiraja N, S Sriram, V Meenaa, JS Kavitha, C Sasikumar and R Rajeswari. Phytochemical screening and antimicrobial activity of the plant extracts of Mimosa pudica L. against selected microbes. J. Ethnobotanical Leaflets 2009; 13: 618-24.

Cite this article as:

V. Prabu Tejaswi, K.Ravishankar. Preliminary phytochemical investigation and in vitro antimicrobial activity of ethanolic extract of Sonneratia apetala plant. Int. Res. J. Pharm. 2013; 4(6):84-87

Source of support: Nil, Conflict of interest: None Declared 